\title{
The Impact of Colonizer on the Colonized: A Postcolonial Study of Nigerian Igbo Culture and History in Chinua Achebe's Things Fall Apart
}

\author{
${ }^{1}$ Dr. Pona Mahanta, Retd., ${ }^{2}$ Dibakar Maut \\ ${ }^{1}$ Head (English), Dibrugarh University, Dibrugarh, Assam \\ ${ }^{2}$ (Asst.Professor), Department of English, Tingkhong College Tingkhong, Dist. Dibrugarh, Assam, Pin-786612
}

\begin{abstract}
The aim of this study is to critically examine from postcolonial point of view how the so called modern Christianity displaced the primitive Igbo religion, its history and culture in the process of pacification by European powers as depicted in Chinua Achebe's Things Fall Apart. He attempted to understand both the merits and demerits of the culture. He even seems to show that a culture or religion which cannot change itself with time would obviously fall apart. For the Hypothetical statement of the study we hold that the primitive Igbo history and culture was in a form of democratic and well balanced state which was not inferior to that of the colonizer. Given the chance, the Igbos could have developed equally to a 'modern' and evolved culture and religion in due time. The modern European cultures were also primitive in their past. They have developed in course of time only with different degrees. But it must be remembered that the 'modernity' associated with 'Christianity' is mostly for material progress. Any nation, culture or religion may get advantages for such material progress. But the imposition of developed race's religion over other less developed races is definitely unjust.The Igbo thought to protect their religion and way of life but could not do so mostly for the pacification of the colonizers, but their inner drawbacks also contribute to their falling apart.
\end{abstract}

Key words: Igbo religion, Things Fall Apart,pacification, post colonialism.

\section{Aims and Objectives \& Research Methodology}

The aim of this study is to critically examine from postcolonial point of view how the so called modern Christianity displaced the primitive Igbo religion, its history and culturein the process of pacification by European powers. He attempted to understand both the merits and demerits of the culture. He even seems to show that a culture or religion which cannot change itself with time would obviously fall apart.

For the Hypothetical statement of the study we hold that the primitive Igbohistory and culture was in a form of democratic and well balanced state which was not inferior to that of the colonizer. Given the chance, the Igbos could have developed equally to a 'modern' and evolved culture and religion in due time. The modern European cultures were also primitive in their past. They have developed in course of time only with different degrees. But it must be remembered that the 'modernity' associated with 'Christianity' is mostly for material progress. Any nation,culture or religion may get advantages for such material progress. But the imposition of developed race's religion over other less developed races is definitely unjust.

This study is concentrated on the novel Things Fall Apart and its presentation of Igbo culture history and so it does not claim to give final conclusions about the whole Afican literature in the same tradition. The methods adopted for the study is based on the primary sources like the original text and interviews as well as secondary sources like criticisms, reference materials with textual discussions.

\section{Definition of Post Colonialism and Colonialism}

The Post - colonial Literature and theory investigate what happens when two cultures clash and one of them with accompanying ideology empowers and deems itself superior to other. The writers of Empire Writes Back use the term 'post-colonial' to cover all the culture affected by the imperial process from the moment of colonization to the present day" ( Ohadike, iii - iv ). Post-colonialism marks the end of colonialism by giving the indigenous people the necessary authority and political and cultural freedom to take their place and gain independence by overcoming political and cultural imperialism.Postcolonial discourse was the outcome of the work of several writers such as AimeCesaire, Frantz Fanon, NgugiWaThiango, Edward Said, Bill Ashcroft and his collaborators, GayatriSpivak, HomiBhabha, Aizaz Ahmad and others. 
(a) Post colonialism:

The concept of Post-colonialism (or often postcolonialism) deals with the effects of colonization on cultures and societies. The term as originally used by historians after the Second World War such as 'postcolonial state', where 'post-colonial' had a clearly chronological meaning, designating the post-independence period. However, from the late 1970s the term has been used by literary critics to discuss the various cultural effects of colonization. Although the study of the controlling power of representation in the colonized societies had begun in the late 1970s with the text such as Said's Orientalism, and led to the development of what came to be called 'Colonialist Discourse Theory' in the work of critics such as Spivak and Bhabha, the actual term 'postcolonial' was not employed in these early studies of the power of colonialist discourse to shape the form and opinion and policies in the colony and metropolis.

"Postcolonialism", in the words of Charles E. Bressler, "is an approach to literary analysis that concerns itself particularly with literature written in English in formerly colonized countries"( Ohadike, v ). It usually excludes literature that represents either British or American viewpoints, and concentrates on Writings from colonized cultures in Australia, New Zealand, Africa, South America, and other places and societies that were once dominated by European cultural, political and philosophical tradition.

Although there is little consensus regarding the proper content, scope and relevance of postcolonial studies, as a critical ideology it has acquired various interpretations. Like deconstruction and other various postmodern approaches to textual analysis, postcolonialism is a heterogeneous field of study where even its spelling provides several alternatives. The critics are not in agreement whether the term should be used with or without hyphen : i. e. 'Post-colonial' and 'postcolonial' have different meanings. The hyphenated term 'Postcolonialism' marks a historical period as is suggested by phrases like 'after colonialism', 'after independence', 'after the end of empire' whereas the term 'postcolonialism' referring to all the characteristics of a society or culture from the time of the colonization to the present.

As a historical period, post-colonialism stands for the post - second World War decolonizing phase. Although the colonial country achieved political freedom, the colonial values do not disappear with the independence of a country. According to Bill Aschcroft, Griffith \& Tiffin, "The semantic basis of the term 'post-colonialism' might seem to suggest a concern only with the national culture after the departure of the imperial power" (Ashcroft, et al,1.)

It seems that Postcolonial theory emerged from the colonized peoples' frustrations, their direct and personal cultural clashes with the conquering culture, and their fears, hopes and dreams about their future and their own identities. How the colonized respond to changes in the language, curricular matters in education, race differences, and a host of other discourses, including the act of writing become the context and the theories of postcolonialism. The project of postcolonialism is not only applicable to the students of literature alone, indeed, it seeks to emancipate the oppressed, the deprived and the down-trodden all over the world.

Thus, the term 'Post-colonialism' marks the end of colonialism by giving the indigenous people the necessary authority and political and cultural freedom to take their place and gain independence by overcoming political and cultural imperialism.

\section{(b) Colonialism:}

The term 'colonialism' is important in defining the specific form of cultural exploitation that developed with the expansion of Europe over the last 400 years. EllekeBoehmer defines 'colonialism' in her book Colonial and Postcolonial Literature as "a settlement of territory, the exploitation or development of resources, and the attempt to govern the indigenous inhabitants of occupied lands"(Boehmer, 2)

Colonialism has been a recurrent feature of human history. The history of colonialism has existed since ancient times. By 1900 almost every country or region in the world had been subjugated by European colonialism at one time or another. The Period after the Second World War saw an upsurge of new independent states. India and Pakistan were granted independence in 1947. France's decolonization was marked by wars in French, Indochina, Morocco, Tunisia, and Algeria. Belgium, Portugal, and the Netherlands all divested themselves of their overseas possessions during the 1950's, 60's and 70s. 'Colonialism' has taken many different form and has engendered diverse effects around the world that can be gauged by thinking about its relationship with the two other terms: 'Capitalism' and 'imperialism'.

\section{Chinua Achebe and the Invention of African Literature}

Achebe is now considered as the inventor of African literature though it is not the first novel about the African past; but it is the first work in which the author represents the African experience in a narrative that sought to be different from the colonial novel. Achebe's goals were modest when he began to conceive and write Things Fall Apart in the early1950s : "I was quite certain that I was going to try my hand at writing, and one of the things that set me thinking was Joyce Cary's novel set in Nigeria, Mister Johnson, which was praised so much, and it was clear to me that this was a most superficial picture... and so I thought if this wasfamous, then 
perhaps someone ought to try and look at this from the inside" (African Writers Talking, 4) which changed the perception of the African readers about their own culture and the institutions of the colonial power. He wants to show the importance of the originality of the African philosophy of storytelling - a much effective way in writing to appeal to the universal brotherhood, humanity and morality of the world. The blind imitations of the European culture and forms of writing would be futile according to him. The great ideal and aim of literature is to give fuller meaning to life. The tragic falling apart of Igbos is successfully portrayed by the author.

Achebe's novel was preceded by other important African novels such as CaselyHayford'sEthiopia Unbound, Sol Plaatj'sMhudi, and Amos Tutuol'sThe Palm-Wine Drinkard. So Achebe is not the inventor with that sense but he was able to capture the anxieties of many African readers in the 1950s through the struggle of Okonkwo " to maintain the intregity of his people against the overwhelming power of colonial rule" ( Simon Gikandi, " Chinua Achebe and the Invention of African Literature " African Writers Series, Heinemann, 2000, p.i) Okonnkwo's story is set between 1860 and 1890 and there was a deep historical psychologiccal parallel between the years when it was concieved, written and published - in 1952-1958.

In the novel Things Fall Apart the central theme can be assumed as the importance of the values that " defineOkonkwo's cultural community, and his own sense of moral order, when the institutions he had fought so hard to sustain collapse in the face of Europeran colonialism."( Gikandi,i ) The period in which Achebe concieved and wrote the novel was a time of anxiety and crisis as by 1952 the colonial rule in Nigeria entered its final phrase and the question was about the nature of the nation after colonialism. The postcolonial culture was in a confusion because by that time the European culture established a strong hold upon the African people especially on a psychological level.

\section{(a) Early Igbo History}

\section{Things Fall Apartand Igbo Culture and History}

The Igbo people are the genuine example of the primitive culture where natural and democratic society was in function. It is the well set culture with much richness like most of so called past of the modern cultures. We can find that the root of cultures is quite the same in different parts of the world. The manifestation of the values and ideas associated with culture may be different in so called modern European cultures. But the basic concepts of African or European cultures are equally respectable and life sustaining:

The Igbo (or Ibo) people form one of the largest ethnic group in Africa, with about 15 million living in Nigeria and another million living outside. Their farming communities are broadly situated between the Niger River in the west and the cross River in the east, stretching from delta swampland near the southern coast through tropical rain forest to open grasslands to the north. ${ }^{1}$

Before the twentieth century the Igbo was not a single people rather they were made up of over two hundred separate group with their customs and languages clearly related. Each group could have been considered a distinct society for such relations and it encompassed perhaps twenty or thirty villages into one group. An Igbo person might have had great difficulty in making himself or herself understood for the vast difference and variety of dialects in Igbo land for even the distance of thirty to forty miles. However, during the colonial period(1900-1960) many Igbo people ventured far from home and accepted the urban centers, the work places, and the institutions of higher learning as the new coming of modernity and development. Many realized that distinct languages were actually the different dialects of the same language and that all Igbo-speaking people had the same basic culture and sociopolitical organization among them as the part of African culture. The concept of a common Igbo identity is a product of the twentieth century which is able to harmonize the variations in Igbo culture throughout Igbo land.

Don C. Ohadike says ${ }^{2}$ about the Igbo creation myth that in the beginning the surface of the earth was covered by water and no humans lived on it. Then one day Chukwu (God) created the first human family, composed of EzeNri, his wife, his sons, and his daughters.EzeNri and his family stood on the top of an ant hill and had nowhere to go because the land was submerged. As they were hungry, Chukwu looked down and took pity on their condition. He gave EzeNri a piece of yam saying, 'Take this, it is edible.' EzeNri and his family ate the yam and found it was good. The myth might be related with the Christian myth of the Bible as it also basically a story explaining our existence in simple terms. The truth of the either is the question of unsolved pondering and not of definite answer.

Again in the Igbo myth we find that the story further explains the our relation with God - the following morning, they were hungry again and EzeNri prayed to God for more yam. Chukwu listened attentively and then gave him some yam seeds saying, ' Plant these and you will have an abundance of yams. ' EzeNri accepted the yam seeds with gratitude and said to Chukwu, ' But the land is covered with water. ' Chukwu instructed him to send for Awaka blacksmiths. They came with their bellows and blew until the land was dry. After that Chukwu askedEzeNri to sacrifice his first son and his first daughter and plant the yam seeds in their graves. EzeNri again obeyed. Shortly afterwards, yam and cocoyam tendrils sprouted from his children's graves. EzeNri harvested yams and cocoyam and shared them among the Igbo people and the cultivation begun. ${ }^{3}$ This story establishes the 
Igbo people's belief in a supreme god (Chukwu) who created all things and demanded obedience. It also suggests that religion has long been an integral part of Igbo life. The myth points to the origins of agriculture, the antiquity of the family, and the importance of iron working in shaping the Igbo community. "Above all, since this myth makes no mention of migrations from distant places - as opposed to the majority of African traditions of origin - it suggests that the Igbo people have occupied their present locale for a very long time, a suggestion that is confirmed by archaeology." ${ }^{4}$

Today's archaeological evidence shows today's Igbo people and their ancestors were the original settler in roughly the same geographical region for two thousand years or more. Much of the material culture of present-day Igbo people resembles that of the people settled in certain locations in Igbo land around 1,000 BC:

"At Afikpo, present-day pottery resembles that produced about 3,000 years ago. At one of the Afikpo sites, the number of stone implements gradually decreased as the amount and variety of pottery increased, showing the transition from hunting and gathering to agriculture." ${ }^{5}$

Further, it is true that the Igbo people have used and forged iron for centuries, and their oral traditions are rich with accounts of iron working and iron use. At Lejja, a small town situated about ten miles south of Nsuskka, the ancient iron-working settlement existed where smelting was done in a pit or bowl furnace. The primitive techniques were quite useful and successful at that time. Gradually, this art flourished in Igboland:

Over time, Igbo improved their technological skills and began to produce sophisticated metal tools such a spearheads, arrowheads, swords, hoes, knives, earrings, finger rings, bracelets, anklets, hammers, anvils, tweezers, scissors, and cooking pots. By the first millennium of the Christian era, they were already producing bronze masks and figurines, of the types that archaeologists discovered in IgboUkwu."

By the widespread use of iron tools enabled the Igbo people to make better use of the forest. With iron tools they grew yams which are the principal staple food of them as well as cocoyams, bananas, plantains etc. These iron tools also helped them to cut down fruits from the tall palm trees, and process them into edible and medicinal oils. The current high density of the Igbo population is mainly for the antiquity and effectiveness of yam cultivation and their skills at exploiting the oil palm as supported by modern scholars.

At its fully developed stage, the Igbo agricultural system was based on shifting cultivation, a type of rotating cultivation where the same fields were planted for several years in succession and then were left fallow to regain their fertility. Crops did best on forest land cleared for the first time, but some people, either unwilling or unable to handle the back-breaking amount of work required to clear virgin forest, planted their yams continuously on old farm lands and reaped poor harvests as a result. In Things Fall ApartOkonkwo's father is portrayed as too lazy to clear forest land; he prays to the spirits to grant him a better harvest but is rebuked for his own lack of intiative. ${ }^{8}$ The importance of hard work is the root of success which is also the practical belief of the Igbo. They are not 'superstitious' in this regard; rather much reasonable and practical.

\section{(b) Social and Political Structures}

A striking feature of Igbo society was the lack of centralized political structures. The existence of democracy was the great achievement and proof of the high culture. The Igbo lived in autonomous villages and towns, rules by their elder. With a few exceptions, they organized themselves in patrilineal-lineage groups organized along lines of descent from father to son. Relationships were based on blood ties, and each person traced his or her descent to three groups. First, a person belonged to the smallest social unit known as uno, or house. This was a natural family, consisting of a man, his wife or wives, and their children. The second group was the umunna, or lineage, composed of a number of related houses." Finally, a group of lineage formed a compact village or town, obodo. This was the highest territorially defined authority of the Igbo." ${ }^{9}$

A town or compact village was sometimes named after its founder, or after a striking geographical feature that best described its location or also after the most important 'sociological circumstances' that surrounded its foundation. The members of a lineage were blood relatives and each lineage was a semi autonomous unit within a town. Each house, lineage, and town was headed by a headman, onyisi, who acquired the position by virtue of his age. There were town meetings which were usually held in the town square, but the most important lineage and house meetings were held in the obi (meeting shed) of the most senior elders. Interaction between towns was limited and they were regulated by goodwill, mutual respect, and diplomacy." Wars often broke out when these failed." ${ }^{10}$ But in Okonkow's case, as Raymond Williams says, "... Okonkow, is destroyed in a very complicated process of internal contradictions and external invasion." ${ }^{11}$ nor he could represent all the good traits of the system to full. The Igbo communities were known as 'extremely democratic', yet they had no centralized governments for running the community. The Igbo subscribed to the principal of direct participation in government which is a much democratic concept. Their entire social and political structure revolved around the idea of "cross-cutting ties". The five most important cross-cutting institutions were the councils of elders, age-groups, councils of chiefs, women's associations, and secret societies. Without them, the Igbo society would be starved of its essence and would disintegrate. As seen in Things Fall Apart the 
traditional Igbo communities did indeed fall apart in the twentieth century when the Europeans destroyed their cross-cutting ties in the process of colonial rule.

\section{(c) Council of Elder}

It was a very important centre of power in the Igbo society with much authority and controle in a democratic depth. Matters affecting lineage members were discussed at the meeting of its elders, ndisi or indichie, with the assistance of the adult members of the lineage as seen in Things Fall Apart In inter-lineage disputes, elders from the affected lineage met to discuss solution. The lineage head derived his authority from the group's respect for him as the oldest living representative of the founding ancestors. He was the custodian of ancestral lands, the keeper of the ritual objects that symbolized political authority, and the group's spiritual and temporal head. Even though he was the religious, executive, and judicial head of his lineage, he would not act without their approval- " no action would be taken until an issue had been fully argued at a lineage meeting and some degree of consensus achieved." ${ }^{12}$

The wise and democratic setting and functioning of these authorities were praiseworthy and practically successful.

\section{(d)Age-Groups}

An age-group association were known as ogbo or otu and composed of men (or women) who were of about the same age. All residents of a town born within a few years of each other belonged to the same agegroup, with 'separated sections' for men and women. The association was named after a major event that was taking place at the time of its members' birth - for example, there were" the Biafran War age-group, ogboaya Biafra ( those born between 1967 and 1970), the Second World War age-group, ogboaya Hitler (1939-1945), and the influenza age-group, ogboinfelunza (1918-1921)." The exact age-span in an age-group varied from town to town, but the most common were the 'three and five -year intervals.' This age-group system enabled societies without written records to remember past events and also helped them assign special duties and responsibilities to the different sergeants of the community, in accordance with the principle of seniority. There was also the junior age -groups (age 15and below) which did "minor jobs like fetching water, cleaning footpaths, sweeping the street and town squares, and running errands." ${ }^{13}$

In the middle age-groups ( 16 to about 40 years of age) the men were the fighters and they formed the fighting forces of the clan. If five years separated one age-group from the next, there would be up to five distinct age-groups in the category. In wars, each age-group acted as a 'separate regiment', under a leader who belonged to an older age-group. These middle age-groups also felled and cleared the bush at the beginning of each planting season. They functioned as the executive arm of the government in the modern sense and would apprehend fugitives . After marriage, young women "would become active in the appropriate women's association." ${ }^{14}$

The senior male age-groups (those aged 40 and above) were responsible for judicial matters. Their usual decisions were related to the questions like "when a town should go to war, how an offender should be punished, when the various agriculture cycles would open and when the annual festivals would be held." ${ }^{15}$

It is certain that the age-group system promoted respect and comradeship among the people and acted as a powerful and effective way of social as well as political set up. The juniors of each section respected and were liable to the seniors and expected the same treatment when they advanced to 'higher grades'. The members of a group acted together, and the "friendships they cultivated in childhood remained intact throughout life." ${ }^{16}$

It is seen that Igbo age group system was useful to coordinate the social setup of Igbos and it generated community feeling. In this sense, Igbo society was very systematic and democratic in nature .

\section{(e)The Acquisition of Titles and Council of Chiefs}

The Igbo people emphasized personal achievement but succession to titles was not by birth. Only some Igbo men managed to acquire prestigious titles, enabling them to be acknowledged as great men or chiefs who are the real successful persons of the time. Titled chiefs formed their own council and represent their communities to outsiders with enough authority as well as democratic responsibilities.

Though most Igbo men eagerly sought admission into the council of chiefs all could not succeed. Every Igbo man began his life as an apprentice as we see in the case of Okonkwo in Things Fall Apart. A young boy "accompaned his father or uncle to the farm and rendered as much assistance as he could" and as he grew older he learned "that marriage, wealth, and the acquisition of titles enabled indivituals to advance socially." ${ }^{17}$ Okonkwo struggles severely in his cultivation though he was the greatest wrestler of the nine villages. Untill a man could attain certain titles, "he could not dress in certain ways, or take a piece of kola nut before other people which shows the essential status of the person in the society."18

These titles cost money; so only men with exceptional abilities and good luck ever bought all the available titles. Ohadike says: 
The taking of the higher titles demanded the payment of expensive initiation fees, accompanied by elaborate feasting and dancing. Throughout Igbo land, a man who failed to progress beyond the most junior titles was a man without status in the eyes of his people ${ }^{19}$

Okonkwo's father is the example of the fate of idle men in Igbo society not withstanding his artistic taste and tragic end. Ohadike writes:

" The highest title in many igbo communities (and the one allluded to inOkonkwo's village) was ozo( or any of its variants: eze, nze, alo, and ichie). ${ }^{120}$ To qualify for the ozo title, a man must have acquired the junior titles and discharge all the duties normally assigned to members of the junior titles 'groups. He must have accumulated enough wealth and completed the ceremonies connected with the second burial of his father.Thus, no man could attain a status that might equal or exceed his father's while the latter was still alive.

The Igbo believed that no man could inherit immortality; it must be acquired through a process of titletaking called 'ichi-echichi,' or secure the breath of life', to attain immortality or god ship. The Igbo word chi represents invisible forces, spirits and personal gods; "it is the root of such word as Chukwo (god), ichie, an immortal or a tilted person, and ndiichie, title holders ". ${ }^{21}$

Only men who achieved this ritual death and resurrection could attain immortality. An ozo man was a person who had received the gift of immortality. He was no longer an ordinary human, but a god. To purchase the highest title was, therefore, to be born again, to be admitted into "the association of rules, otuochichi, and to be intiated into the cult of the ancestors, otundichie ". ${ }^{22}$ The highest title spared its holder the indignity of manual labor in the Igbo society. It guaranteed him a seat in the council of chiefs and it reserved for him portion of fees paid by new intiates into the titles association. Further it gave him rights to certain portions of livestock slaughtered in his lineage. A title man was greeted with highsounding salutations such as igwe( His Highness ) and ogbuefi( he who slaughter bulls ).

" Theozo title lost its appeal in the twentieth century when colonial officers stripped traditional Igbo chiefs of their power and then subordinated them to British-appointed warrant chiefs and Western-educated Africans ." ${ }^{23}$

The system is clearly conveniant to the smooth functioning of the Igbo society with a democratic setup . The value given to the ancestors and the positive spiritual system where man can attain perfection was positively present in Igbo society absent unlike many "high" religions.

\section{(f) Women's Associations}

The Igbo women had their own clubs, age-group association, and title associations that complemented those of men. They controlled certain spheres of community life showing the balance in the masculine and feminine existence. Women were perceived to possess superior spiritual well-being and headed many of the traditional cults and shrines. In Achebe's Things Fall Apart the oracle is served by a priestess. Women also gained status by amassing wealth through trading, farming, or weaving, and were treated as ndiogalanya, wealthy persons.

Like an Igbo man, every Igbo woman began her life as an apprentice. From a very young age a girl assisted her mother at home, on the farm, or in the marketplace. As she grew older she learned from experience that hard work, marriage, and membership of certain associations enabled women to advance socially. One of the most important women's associations was otuomu (the Omu society), headed by a female functionary, known as Omu. The desire to join this prestigious association acted as an incentive for hard work and thrift, for only women who had enough wealth to pay for the initiation ceremonies were admitted. The members of the Omu society acted as a pressure group in political matters and imposed fines on men and women who disturbed the peace of the marketplace. They punished quarrelsome women and those who broke certain taboos, like those prohibiting incest and adultery." It was perilous for any man, no matter how influential, to provoke the anger of this association." ${ }^{24}$

The feminine power is evident in quite the same pattern found specially among the tribes of India as well as other 'primitive' cultures of the world. In the Igbo social set up the leaders of the Omu society attended the meetings of the councils of chiefs and elder and participated in discussions affecting the welfare of the citizens. Though they would not themselves take part in wars, they could "decide when to urge the male warrior chiefs to start one". ${ }^{25}$

The Omu society and several other women's associations, acted as checks and balance in the social and political organization of Igbo communities. The otuumuada was an association of women married to the men of a lineage or town. Theoretically, every married woman belonged to both associations, while an unmarried woman belonged only to otuumuada. Men participated in the politics of their home towns alone, but interestingly women execised influence in the politics of both their home towns and the towns of their marriage which is an evidence of feminine power over politics. ${ }^{26}$ In the novel Things Fall Apart , Achebe is showing the " range depth and variety of the nineteenth-century Eastern Nigerian social and personal life, as it was lived, 
before the deluge of colonization especially from 1885 onwards "27 It is also that highness of the 'other' or the primitive (Edward Said, Orientalism, 1978 ) which is destroyed by colonization.

The Igbo people were at a position of a self-reliant existent notwithstanding some drawbacks; but they were certainly lived a meaningful life of their basic culture and world-view. The colonial encounter crushed out the positive traits of the religion in the name of modernization and enlightment through the imposing of Christianity and European culture.

\section{(g) Kingship Organization of Igbos}

From political point of view, the Igbos had no king. Their "kings" were priests (Eze).In the words of Ki-Zerbo: "[Les Ibos] se regroupentparfois sous l'egided'une meme divinite.."(Histoire de l'Afrique Noire d'Hier cl Demain. Paris. Hatier. 1972. p.159.)

There was hierarchy in the socio-political organization as represented by thefollowing pyramid (pyramid proposed by - AderemiBamikunle (Nigeria). Lecture at the University of Saint-Louis (Senegal). 1995.) structure:

- Chiefs

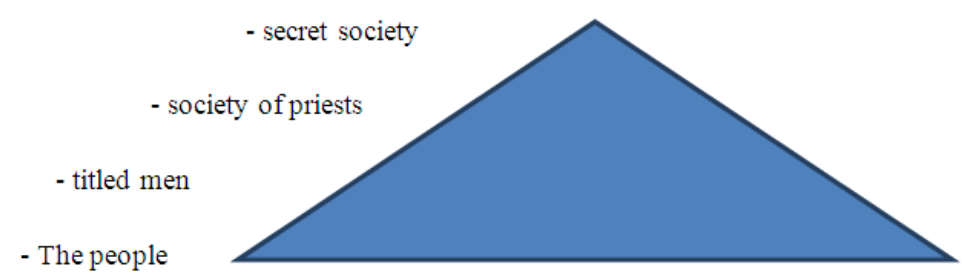

But, in spite of the hierarchy, there was democracy in this organization. TheIgbos evolved a humanistic civilization. Each village had a legislative assembly which called open-air meetings at which everyone was free to give their opinions. This democratic process allowed the highest honours open to every free man. The final decisions were left to the elders; but the decisions did not become"laws" automatically. The democratic process which really existed among the Igbos resembles the fiction of Things Fall Apart. The democratic process in the novel shows the linkage. In the novel, there is no king as it is shown by the following answer to the missionaries:" They asked who the king of the village was, but the villagers told them therewas no king. " We have men of high title and the chief priest and the elders",they said" ( Things Fall Apart, p.105). So, when they first arrived in Mbanta, the missionaries expected to find a king.

\section{(h) Secret Societies}

In Igbo society, there were some secret societies for men and women exclusively and some for both the sexes. These secret societies were very little known to people as the members of such societies took oath of secrecy and never disclose the identity or any information regarding them. They were also serious about the effectiveness of the powers of secret societies as which believed to be weaken if disclosed -

"... many of them functioned as the mouthpiece of ancestors, oracles and spirits. In important judicial matters, masked ancestors ( theegwugwu, or egungun) might appear and pronounce a verdict ."( Don C. Ohadike, "Igbo Culture and History", xxx . )

In chapter ten of Things Fall Apart, the egwugwu decide over the legal village cases. No one disputed over them as nobody thought to be wiser than the egwugwu and if critically examined, the cases were efficiently settled by them .

\section{(i) Igbo Marriage}

The integration to the social group is done after this stage which is determining in the life of the Igbos. Besides, there is a realistic effect with the structures of kinship and particularly marriage. In real life, in Africa, marriage was a fundamental aspect of the survival of the societies and followed a certain number of principles. Polygamy was common. However, in the traditional societies of Africa, young people were not free to marry the girl of their own choice. The parents were the ones who chose for them, according to the relationship that united them with the family of the bride. People adopted marriage in order to fulfill social requirements. Yet, it was characterized by complementarity. The ceremonies that accompanied marriage were various. The way marriage was conceived is close to the depiction in the novel Things Fall Apart . If marriage is examined in the novel, similar things are discovered. In the novel, marriage has a collective function and is marked by three stages:

- fixing the dowry (for example with Obierika's daughter)

- theuri or officialization of the link (Chapter Twelve, with the daughter of

Obierika)

- theisa-ifi (in Mbanta with Uchendu's son Amikwu): the bride must swear that she has never slept with a man since the bridegroom expressed the will tomarry her. In Things Fall Apart, marriage is essentially sealed 
according to a precise ritual of real world. The theme of polygamy recurs in the novel. The negotiations resemble verbal battles between influential members of different families. Achebe uses literature as a social document where he records or preserves the customs, traditions or experiences of his society like a historian.

\section{F. Conclusion}

In the novel Things Fall Apart Achebe's portrayal of the Igbos is not only the attack on the Christian colonizers for their thoughtless destruction of the so called "primitive"culture and the religion; but it is also the self-criticism of the drawbacks of Igbo society. The colonizers used Christianity for their own profit and employed barbaric force to pacify the Igbos. But in the study it is found that the Igbo culture and religion in spite of their drawbacks and superstitions, proved to be wiser in much of its direct clashes with the Christian faith.

The Igbo thought to protect their religion and way of life but could not do so mostly for the pacification of the colonizers, but their inner drawbacks also contribute to their falling apart. The main character Okonkwo in Things Fall Apart is not the self-ruled person in the Gandhian model but the idea of the swaraj comes much near to the self-sufficient Igbo culture and especially in the democratic and peaceful egwugwu. The so called "modern" cultures are seen mostly in terms of material progress and so the slow runners are out of the game. If they can change themselves in time, then only they can survive against the other enforcing religions. In case of the Igbos, the missionaries entered Christianity with the European culture which shattered the whole setup of the clan or the whole structure of the effective society.

\section{End Notes}

${ }^{1}$ Don C. Ohadike, “Igbo Culture and History”( London: Heinemann Educationl,2000), p. i.

${ }^{2}$ Ibid, p. i-ii.

${ }^{3}$ Ibid, p ii.

${ }^{4}$ loc. cit.

${ }^{5}$ loc. cit.

${ }^{6}$ ibid, p.iii-iv

${ }^{7}$ ibid, p. iv.

${ }^{8}$ loc. cit.

${ }^{9}$ loc. cit.

${ }^{10}$ loc. cit.

${ }^{11}$ Raymond Williams, The Country and the City ( New york : Oxford University Press, 1973), .286.

${ }^{12}$ Ohadike, op. cit., p. iv

${ }^{13}$ ibid, p v

${ }^{14}$ loc. cit.

${ }^{15}$ loc. cit.

${ }^{16}$ ibid, p. vii

${ }^{17}$ loc. cit.

${ }^{18}$ ibid, p. viii.

${ }^{19}$ ibid, p ix.

${ }^{20}$ loc. cit.

${ }^{21}$ loc.cit.

${ }^{22}$ loc. cit.

${ }^{23}$ loc. cit.

${ }^{24}$ ibid, p. $x$.

${ }^{25-27}$ loc. cit.

\section{Bibliography}

[1]. Achebe ,Chinua. Morning Yet on Creation Day: Essays, London: Heinemann, 1983.

[2]. Ashcroft, Bill; Gareth Griffiths and Helen Tiffin.The Empire Writes Back: Theory and Practice in Post-Colonial Literatures, London : Routledge, 1989.

[3]. Bhabha,Homi. The Location of Culture, London: Routledge. 1994.

[4]. Bressler,Charles E. Literary Criticism : An Introduction to theory \& Practice, New Jersey: Prentice Hall, 1999.

[5]. Boehmer,Elleke. Colonial and Postcolonial Literature, Oxford and New York : Oxford University Press, 1995.

[6]. Gandhi ,Leela . Postcolonial Theory : A Critical Introduction, Delhi: OUP, 1999.

[7]. Gandhi, Mahatma. Hind Swaraj, Ahamdabad: Navjivan Publishing House, Reprint, 1938.

[8]. Gikandi,Simon. " Chinua Achebe and the Invention of African Literature " , London: Heinemann Educational, 2000.

[9]. Granqvist, Raoul . ed.. Travelling: Chinua Achebe in Scandinavia.Swedish Writers in Africa,Sweden : Umea University, 1990.

[10]. Mukherjee ,Meenakshi, "Interrogating Post-colonialism", Interrogating Post-colonialism : Theory, Text and Context.ed. Harish Trivedi and Meenakshi Mukherjee :Shimla :IIAS, 1996.

[11]. Ohadike ,Don C. “ Igbo Culture and History ”, London: Heinemann Educationl, 2000

[12]. Said. Edward. Orientalism, London : Penguin, 1978.

[13]. Williams, Raymond. The Country and the City, New york : Oxford University Press, 1973. 